\title{
PEMANFAATAN SOFTWARE OPENSOURCE UNTUK VISUALISASI DIGITAL ANGKA METER LISTRIK ANALOG BERBANTUAN GADGET PADA SISTEM MBSS DI ERA REVOLUSI INDUSTRI 4.0
}

\author{
Ahsan Muafa ${ }^{1}$, Asri Dwi Puspita ${ }^{2}$ \\ ${ }^{1}$ Desain Komunikasi Visual, Fakultas Teknik \\ Universitas Maarif Hasyim Latif, Sidoarjo, Indonesia \\ e-mail : ahsanmuafa@dosen.umaha.ac.id \\ 2Teknik Industri, Fakultas Teknik \\ Universitas Maarif Hasyim Latif, Sidoarjo, Indonesia \\ e-mail : asripuspita85@dosen.umaha.ac.id
}

Diterima: 18 Oktober 2019. Disetujui : 12 Nopember 2019. Dipublikasikan : 31 Desember 2019

(C)2019 -TESJ Fakultas Teknik Universitas Maarif Hasyim Latif. Ini adalah artikel dengan akses terbuka di bawah lisensi CC BY 4.0 (https://creativecommons.org/licenses/by/4.0/)

\begin{abstract}
ABSTRAK
Tuntutan pada era revolusi industri 4.0 adalah semua data dapat diakses secara cepat dan daring. Salah satu alat yang dapat dimanfaatkan adalah smartphone. Dengan bantuan smartphone, kita bisa mengakses data secara cepat dan daring. Smartphone juga banyak digunakan orang untuk menunjang aktifitas seharihari. Smartphone banyak digunakan untuk memonitor dan update di media sosial seperti whatsapp, facebook, telegram, istagram dan lain-lain. Salah satu media sosial yang mulai banyak digunakan adalah telegram. Dengan telegram, kita bisa mengirimkan dan menerima pesan secara cepat berupa teks, audio bahkan video. Telegram juga dilengkapi telegram bot (robot telegram). Telegram bot memungkinkan kita mengatur penerimaan dan pengiriman data. Tujuan penelitian ini adalah membuat sebuah desain sistem pelaporan pemakaian energi listrik melalui telegram. Data berupa pemakaian energi listrik dapat diakses oleh pelanggan secara daring melalui media sosial telegram. Metode penelitian yang dipakai adalah penelitian pengembangan. Penelitian dilakukan untuk melihat tingkat keberhasilan desain dalam menjalankan fungsinya. Langkah yang ditempuh antara lain membuat telegram bot yang berperan sebagai robot dalam melayani penyimpanan dan pengiriman data pemakaian listrik pelanggan. Setelah telegram bot tercipta, dilanjutkan dengan pembuatan program untuk meminta telegram bot mengupdate dan memposting kembali data pemakaian listrik yang tersimpan pada server. Data kemudian dikirim ulang oleh telegram bot melalui telegram ke setiap pelanggan yang membutuhkan.
\end{abstract}

Kata kunci: daring; media sosial; smart phone; telegram bot

\section{PENDAHULUAN}

PLN sebagai penyedia listrik menggunakan kwh meter untuk mengukur pemakaian energi listrik. Kwh meter terdiri dari beberapa tipe. Tipe kwh meter yang digunakan antara lain kwh meter analog, semi digital dan digital. Dari data kwh meter inilah PLN mengetahui jumlah pemakaian energi listrik yang dipakai oleh setiap pelanggan dan menentukan tagihannya. Kwh meter ada disetiap rumah pelanggan. Dengan demikian, perlu ada petugas yang datang dari satu rumah ke rumah untuk mencatat angka meter ini. Karena dilakukan secara manual maka sangat mungkin terjadi kesalahan pencatatan oleh petugas.

Kemajuan teknologi saat ini telah berpengaruh terhadap sistem secara umum. Sistem yang dahulu bekerja secara manual telah berubah menjadi otomatis. Dengan kemajuan teknologi seharusnya juga bisa dimanfaatkan untuk meminimalisir kesalahan pencatatan kwh meter. Pelaporan yang dahulu manual dengan mencatat satu per satu kwh meter bisa disederhanakan bahkan diubah menjadi otomatis.

Kemajuan teknologi juga membawa perubahan yang signifikan pada layanan. Salah satu tuntutan pada era revolusi industri 4.0 adalah kecepatan dalam layanan. Berbagai layanan masyarakat seperti layanan untuk mendapatkan informasi secara cepat dan daring juga menjadi kebutuhan masyarakat. Selain kecepatan, layanan masyarakat juga dituntut untuk menerapkan sistem paperless (tanpa kertas). Kini layanan masyarakat seperti perbankan juga sudah mengurangi penggunaan kertas dengan program ebanking. Hampir di semua kegiatan layanan 
masyarakat menerapkan sistem daring. Layanan dapat diakses dari mana saja dan kapan saja.

Untuk memasyarakatkan layanan daring ini maka perlu sarana atau wadah atau media yang bisa mendukung bahkan mempercepat proses layanan. Media yang cocok dan bisa dipakai untuk keperluan tersebut adalah smartphone. Smartphone banyak digunakan masyarakat dalam membantu aktifitas sehari-hari. Dengan bantuan smartphone, kita dapat mencari informasi yang dibutuhkan dari bagian bumi manapun. Dunia terasa dalam genggaman. Informasi apa saja bisa didapatkan dan disajikan secara cepat, real time dan daring.

Semakin banyaknya orang menggunakan smartphone maka semakin membantu pembuatan sistem daring. Karena masyarakat sudah terbiasa atau familiar dengan software yang digunakan. Sehingga proses sosialisasi juga semakin mudah. Telegram sebagai salah satu media social dengan jumlah pengguna besar dapat dijadikan pilihan. Karena banyak fitur yang menarik dan interaktif.

\section{METODE PENELITIAN}

Penelitian yang dilakukan merupakan penelitian pengembangan. Penelitian dilakukan dengan cara mengembangkan program yang menerapkan koding dan berfungsi membuat antar muka antara server dan telegram berbantuan telegram bot.

Pada tahap pra penelitian, survey atau observasi dilakukan ditempat yang banyak menggunakan kwh meter analog. Target sampel data sebagai sampel penelitian dilakukan ke perusahaan yang menerapkan MBSS (multi buyer single seller) yang masih mempertahankan penggunaan kwh meter analog untuk mengukur pemakaian beban listrik. Untuk keperluan tersebut maka survey dilakukan didaerah pusat beban seperti bangunan superblok mall, office dan resident.

Untuk membuat sistem pelaporan pemakaian energi listrik secara daring maka penelitian ini dilakukan dalam beberapa tahap. Tahap pertama adalah digitalisasi angka meter listrik. Tahap kedua adalah pengolahan data hasil digitalisasi untuk menentukan angka meter terakhir saat ini. Tahap ketiga adalah menghitung pemakaian energi berdasarkan selisih angka meter akhir-awal dan menghitung tagihan listrik bulan berjalan.

Digitalisasi angka meter analog dapat ditempuh dengan beberapa cara yaitu pengenalan karakter angka meter listrik yang berupa gambar, sensor kecepatan putaran kwh meter serta sensor arus dan tegangan. Metode pertama dilakukan dengan cara mengambil gambar angka meter listrik menggunakan kamera atau gawai lainnya. Dari hasil photo ini kemudian diolah untuk dilihat karakter atau teks yang ditunjukkan gambar. Karakter hasil proses merupakan besaran digital yang bisa diolah menggunakan computer. Metode kedua dilakukan dengan memanfaatkan sensor kecepatan putaran mekanis kwh meter. Pemakaian energi listrik dihitung berdasarkan jumlah putaran piringan kwh meter. Semakin banyak putaran maka semakin banyak penggunaan energi listrik oleh pelanggan. Hasil hitung putaran merupakan besaran digital yang bisa diolah menggunakan computer. Metode ketiga dilakukan dengan memasang transduser arus dan tegangan. Transduser akan mengeluarkan tegangan sebagai outputnya. Dengan bantuan modul arduino, diperoleh besaran digital angka meter listrik.

Untuk membuat sistem laporan daring menggunakan media social telegram, dapat dilakukan dengan memanfaatkan telegram bot (robot telegram). Telegram bot adalah robot pada telegram yang bisa diperintahkan untuk melakukan apa saja sesuai dengan perintahkan. Telegram bot berfungsi sebagai eksekutor perintah yang kita masukan. Untuk mendukung pelaporan secara daring maka telegram bot diperintahkan untuk selalu mengupdate apakah ada perintah terlebih dahulu kita membuat pembuatan telegram bot.

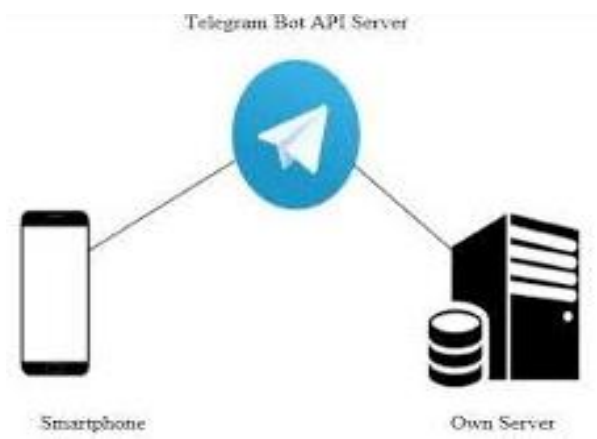

Gambar 1. Hubungan antara gadget, server dan telegram bot

Secara keseluruhan, desain sistem pelaporan yang telah dibuat mengikuti flowchart pada Gambar 2.

Pada tahap pra penelitian, survey atau observasi dilakukan ditempat yang banyak menggunakan kwh meter analog. Target sampel data sebagai sampel penelitian dilakukan ke perusahaan yang menerapkan MBSS (multi buyer single seller) yang masih mempertahankan penggunaan kwh meter analog untuk mengukur pemakaian beban listrik. Untuk keperluan tersebut maka survey dilakukan didaerah pusat beban seperti bangunan superblok mall, office dan resident. Dari survey dilapangan diketahui bahwa terdapat beberapa jenis kwh meter yang 
digunakan antara lain analog, semi digital dan digital.

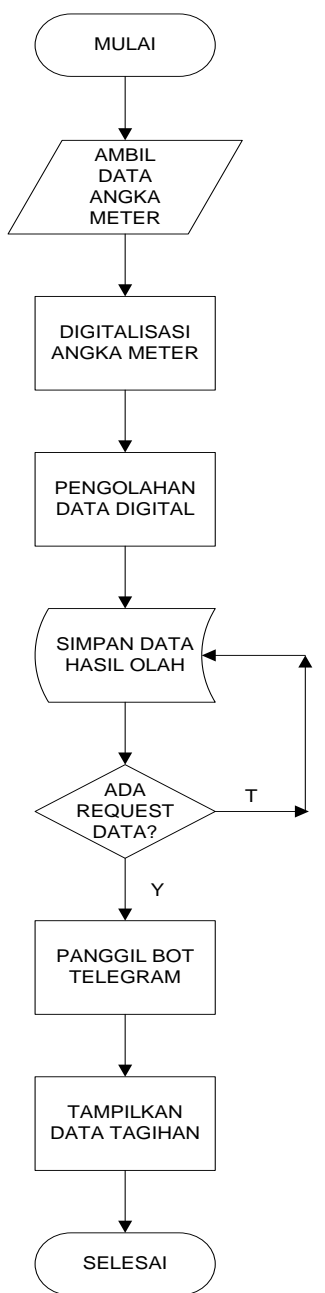

Gambar 2. Flowchart sistem pelaporan melalui media sosial telegram

\section{HASIL DAN PEMBAHASAN}

Dari survey dilapangan diketahui bahwa terdapat beberapa jenis kwh meter yang digunakan antara lain analog, semi digital dan digital.

Berdasarkan sistem kelistrikan yang diukur, kwh meter terbagi atas dua sistem kelistrikan yaitu kwh meter satu phase dan kwh meter tiga phase.

Tabel 1. Jumlah kwh meter analog yang digunakan

\begin{tabular}{lll}
\hline No & Merk & Jumlah \\
\hline 1 & Itron & 397 \\
2 & Fuji & 119 \\
3 & Schlumberger & 60 \\
4 & Actaris & 168 \\
5 & Merk lain & 28 \\
\hline & Total & 772
\end{tabular}

Berdasarkan merk, kwh meter yang dipakai terdiri atas merk fuji, actaris, schlumberger dan itron. Dari 772 kwh meter yang dipakai terdapat 397 buah kwh meter merk itron atau sekitar 51\% dari total kwh meter yang digunakan seperti pada Tabel 1.

Untuk mendapatkan sampel yang merepresentasikan populasi penelitian maka kwh meter analog itron sebagai kwh dengan jumlah terbanyak, dipilih sebagai sampel data.

Setelah survey dilakukan dan mendapatkan representasi jenis kwh meter yang digunakan secara luas maka langkah selanjutnya adalah menyiapkan sarana yang akan digunakan untuk desain sistem pelaporan. Sesuai dengan tuntutan revolusi industri 4.0 yang menghendaki semua besaran data disajikan dalam bentuk digital maka besaran listrik dari kwh meter analog tersebut di atas dapat dimonitor secara daring bila dikonversikan ke bentuk digital terlebih dahulu. Sarana yang digunakan antara lain gadget yang dilengkapi kamera untuk digitalisasi angka meter menggunakan konversi image to text, penggunaan sensor untuk menghitung jumlah putaran piringan kwh meter analog serta sensor arus dan tegangan untuk menghitung pemakaian energi listrik.

Teknik konversi pertama dilakukan dengan mengambil gambar angka kwh meter dan menyimpan dalam bentuk file gambar. Berdasarkan file gambar angka kwh meter tersebut maka dapat ditentukan berapa angka meter terakhir pada kwh meter. Dengan demikian, jumlah pemakaian energi listrik dapat ditentukan dengan cara mengurangkan angka meter sekarang dengan angka meter satu bulan yang lalu. Namun hasil konversi gambar ke teks menunjukkan bahwa ketepatan konversi masih belum maksimal. Hal ini karena kualitas gambar hasil photo terlihat kurang maksimal seperti ada gambar yang blur, kurang terang serta posisi yang tidak tepat lurus bidang. Kurang maksimalnya kualitas gambar karena pengambilan gambar yang tidak tepat antara lain lokasi kwh meter yang kurang pencahayaan serta posisi pengambil gambar yang tidak lurus dengan objek.
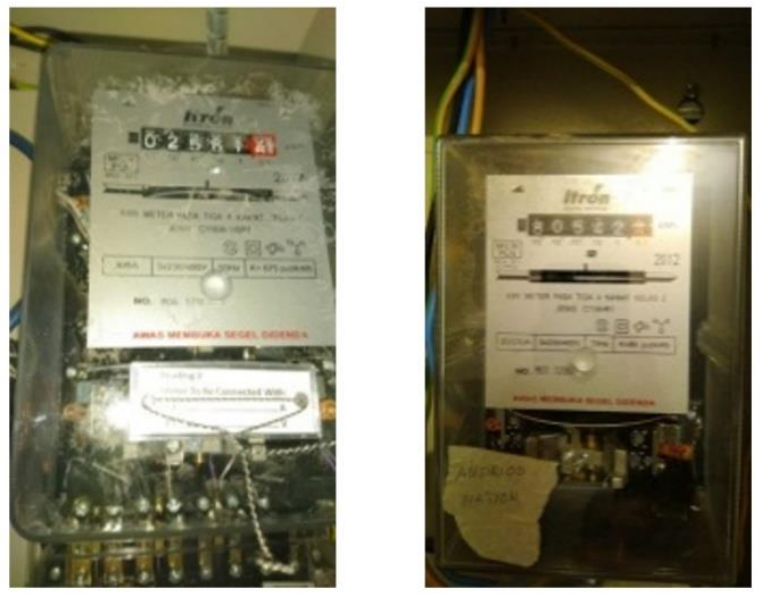

Gambar 3. Beberapa hasil photo yang tidak maksimal 
Dari proses konversi image to text didapatkan hasil sebagai berikut:

Tabel 1. Contoh hasil konversi image to text area 1

\begin{tabular}{llll}
\hline Bulan & Lokasi TP1 & Hasil & Keterangan \\
\hline Mei & 94023.5 & & Valid \\
Jun & 94656.0 & Tidak Valid \\
Jul & 95372.1 & & Tidak Valid
\end{tabular}

Tabel 2. Contoh hasil konversi image to text area 2

\begin{tabular}{llll}
\hline Bulan & Lokasi TP2 & Hasil & Keterangan \\
\hline Mei & 17051 & 17051 & Valid \\
Jun & 24077 & 24077 & Tidak Valid \\
Jul & 26957 & 26957 & Valid \\
\hline
\end{tabular}

Tabel 3. Contoh hasil konversi image to text area 3

\begin{tabular}{llll}
\hline Bulan & Lokasi TP3 & Hasil & Keterangan \\
\hline Mei & 83888.2 & & Valid \\
Jun & 84251.5 & Valid \\
Jul & 84619.4 & & Tidak Valid
\end{tabular}

Tabel 4. Contoh hasil konversi image to text area 4

\begin{tabular}{llll}
\hline Bulan & Lokasi TP4 & Hasil & Keterangan \\
\hline Mei & 3978.3 & & Valid \\
Jun & 4387.2 & Tidak Valid \\
Jul & 4868.3 & Valid
\end{tabular}

Tabel 5. Contoh hasil konversi image to text area 5

\begin{tabular}{llll}
\hline Bulan & Lokasi TP5 & Hasil & Keterangan \\
\hline Mei & 4564.1 & Valid \\
Jun & 4817.9 & Valid \\
Jul & 5097.9 & Valid
\end{tabular}

Tabel 6. Contoh hasil konversi image to text area 6

\begin{tabular}{llll}
\hline Bulan & Lokasi TP5 & Hasil & Keterangan \\
\hline Mei & 4564.1 & & Valid \\
Jun & 4817.9 & & Valid \\
Jul & 5097.9 & & Valid
\end{tabular}

Cara yang kedua adalah digitalisasi angka meter listrik menggunakan perhitungan jumlah putaran piringan kwh meter. Perhitungan jumlah putaran dilakukan dengan cara memasang sensor pada kwh meter. Sensor mendeteksi berapa kali piringan berputar selama satu bulan. Dari jumlah total putaran piringan kwh meter selama satu bulan maka perhitungan pemakaian energi listrik dapat ditentukan. Pemakaian energi listrik sama dengan total jumlah putaran dibagi dengan standar putaran/kwh yang dimaksud.

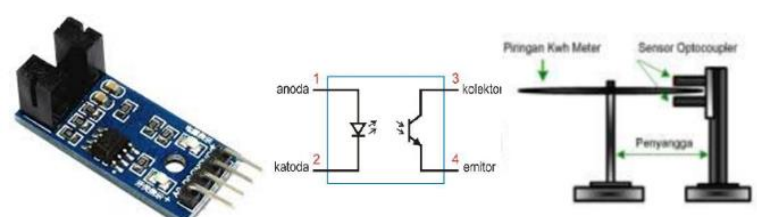

Gambar 4. Modul, rangkaian dan penempatan Sensor kecepatan putaran piringan

Dari penerapan sensor kecepatan putaran piringan kwh meter didapatkan data sebagai berikut:

Tabel 7. Hasil ukur menggunakan counter

\begin{tabular}{llll} 
Bulan & Lokasi TP1 & Pemakaian Listrik & Keterangan \\
\hline Jun & 50560 & 632.5 & Tercatat 630 \\
Jul & 57200 & 716.1 & Tercatat 715
\end{tabular}

Tabel 8. Hasil ukur menggunakan counter

\begin{tabular}{llll}
\hline Bulan & Lokasi TP2 & Pemakaian Listrik & Keterangan \\
\hline Jun & 560800 & 7026 & Tercatat 7010 \\
Jul & 230080 & 2880 & Tercatat 2876
\end{tabular}

Tabel 9. Hasil ukur menggunakan counter

\begin{tabular}{llll}
\hline Bulan & Lokasi TP3 & Pemakaian Listrik & Keterangan \\
\hline Jun & 289600 & 363.3 & Tercatat 362 \\
Jul & 292800 & 367.9 & Tercatat 366
\end{tabular}

Tabel 10. Hasil ukur menggunakan counter

\begin{tabular}{llll}
\hline Bulan & Lokasi TP4 & Pemakaian Listrik & Keterangan \\
\hline Jun & 273375 & 408.9 & Tercatat 405 \\
Jul & 322650 & 480.8 & Tercatat 478
\end{tabular}

Tabel 11. Hasil ukur menggunakan counter

\begin{tabular}{llll}
\hline Bulan & Lokasi TP5 & Pemakaian Listrik & Keterangan \\
\hline Jun & 162000 & 253.8 & Tercatat 240 \\
Jul & 182250 & 280.0 & Tercatat 270
\end{tabular}

Tabel 12. Hasil ukur menggunakan counter

\begin{tabular}{llll}
\hline Bulan & Lokasi TP6 & Pemakaian Listrik & Keterangan \\
\hline Jun & 108000 & 1363.4 & Tercatat 1350 \\
Jul & 127600 & 1610.3 & Tercatat 1595
\end{tabular}

Cara ketiga adalah digitalisasi angka meter listrik menggunakan perhitungan arus dan tegangan. Untuk mendapatkan nilai arus dan tegangan beban maka pada instalasi kwh meter analog dipasang sensor arus dan tegangan beserta transdusernya. Dengan memasang sensor arus dan tegangan serta memasang sensor arus dan tegangan yang digunakan untuk mengukur besarnya arus dan tegangan pada beban. Dari hasil ukur arus dan tegangan maka besarnya pemakaian listrik dapat dihitung dan disajikan dalam bentuk digital.
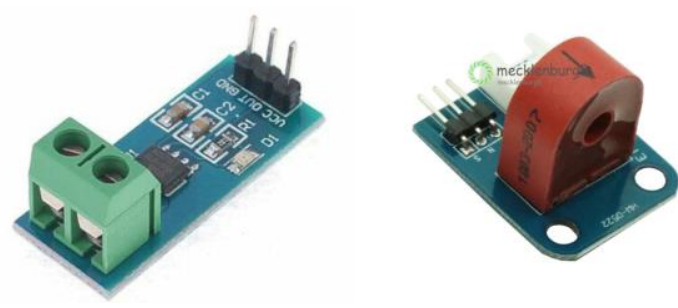

Gambar 5. Sensor arus

Dari penerapan sensor arus didapatkan data sebagai berikut:

Tabel 13. Hasil konversi transduser arus ke tegangan

\begin{tabular}{llll}
\hline Bulan & Lokasi TP1 & Pemakaian Listrik & Keterangan \\
\hline Jun & 632.5 & Tercatat 631.5 \\
Jul & 716.1 & Tercatat716 \\
\hline
\end{tabular}

Tabel 14. Hasil konversi transduser arus ke tegangan

\begin{tabular}{llll}
\hline Bulan & Lokasi TP2 & Pemakaian Listrik & Keterangan \\
\hline Jun & 7026 & Tercatat 7026 \\
Jul & 2880 & Tercatat 2880 \\
\hline
\end{tabular}

Tabel 15. Hasil konversi transduser arus ke tegangan

\begin{tabular}{llll}
\hline Bulan & Lokasi TP3 & Pemakaian Listrik & Keterangan \\
\hline Jun & 363.3 & Tercatat 363 \\
Jul & 367.9 & Tercatat 368 \\
\hline
\end{tabular}


Tabel 16. Hasil konversi transduser arus ke tegangan

\begin{tabular}{llll}
\hline Bulan & Lokasi TP4 & Pemakaian Listrik & Keterangan \\
\hline Jun & 408.9 & Tercatat 409 \\
Jul & 480.8 & Tercatat 480.5 \\
\hline
\end{tabular}

Tabel 17. Hasil konversi transduser arus ke tegangan

\begin{tabular}{llll}
\hline Bulan & Lokasi TP5 & Pemakaian Listrik & Keterangan \\
\hline Jun & 253.8 & Tercatat 253.5 \\
Jul & 280.0 & Tercatat 280 \\
\hline
\end{tabular}

Tabel 18. Hasil konversi transduser arus ke tegangan \begin{tabular}{llll}
\hline Bulan & Lokasi TP6 & Pemakaian Listrik & Keterangan
\end{tabular}

\begin{tabular}{lll}
\hline Jun & 1363.4 & Tercatat 1363 \\
Jul & 1610.3 & Tercatat 1610 \\
\hline
\end{tabular}

Data kemudian disimpan pada server untuk selanjutnya dikirim ke pelanggan. Dengan menyimpan data di server maka setiap pelanggan bisa melakukan akses informasi jumlah pemakaian energi listrik yang telah digunakan selama satu bulan terakhir.

Langkah selanjutnya adalah membuat sebuah sistem pelaporan interaktif dengan memanfaatkan software opensource yang didukung oleh komunitas yang kuat. Salah satunya melalui media sosial. Telegram, sebagai salah satu media sosial yang bersifat opensurce, dapat dimanfaatkan untuk keperluan ini. Pengguna telegram dari waktu ke waktu semakin banyak.

Pemilihan telegram untuk membuat sistem pelaporan secara daring karena telegram menyediakan fitur telegram bot (robot telegram). Dengan telegram bot kita bisa membuat sistem pelaporan interaktif. Telegram juga mampu bekerja pada multiplatform. Sehingga lebih mudah dalam operasionalnya.

Untuk membuat sebuah sistem interaktif maka langkah awal yang dilakukan adalah membuat telegram bot. Telegram bot yang dibuat merupakan bot kita, dan dapat diperintah untuk melakukan apa saja sesuai dengan apa yang diperintahkan. Untuk membuat sebuah bot bisa dilakukan melalui @botfather. Dengan mengakses @botfather pada telegram maka kita bisa membuat sebuah robot sesuai dengan keinginan kita. Pada akhir pembuatan bot akan didapatkan token. Token ini adalah identitas bot yang baru dibuat. Dengan token ini pemilik bot bisa berinteraksi dengan server dan lain-lain.

Untuk melakukan interaksi dengan server dibutuhkan telegram API. API merupakan singkatan dari application progamming interface. API adalah sekumpulan fungsi dan prosedur yang memungkinkan untuk melakukan kreasi terhadap aplikasi dalam mengakses fitur atau data sistem operasi, aplikasi atau layanan lainnya.

Dengan hasil penerapan di atas maka dapat disimpulkan bahwa desain sistem pelaporan dengan media sosial telegram dapat dimanfaatkan untuk membuat sistem pelaporan pemakaian listrik pelanggan

\section{PENUTUP}

Dari penelitian yang dilakukan dapat disimpulkan bahwa telegram dapat dimanfaatkan untuk desain sistem pelaporan yang interaktif sebagai media sosial. Sebagai saran untuk peneliti yang tertarik pada hardware agar dilanjutkan penelitian tentang power supply transduser. Pada penelitian ini power transduser berasal dari sumber terpisah. Untuk penelitian lanjutan bisa meneliti tentang penyediaan modul transduser termasuk power supply didalamnya.

\section{UCAPAN TERIMA KASIH}

Terima kasih penulis sampaikan kepada pemerintah Republik Indonesia melalui Kemenristek dikti dan LLDIKTI wilayah 7 Jawa Timur, yang telah memberikan kesempatan dan hibah dana kepada penulis untuk melaksanakan penelitian ini. Tak lupa penulis sampaikan pula terima kasih kepada pimpinan PT Pakuwon Jati tbk beserta karyawan, yang telah membantu hingga terselesainya penelitian ini.

\section{DAFTAR PUSTAKA}

Erik, P. (2016). Pengenalan Pola Angka Untuk Pencatatan Kwh Meter Secara Otomatis Menggunakan Metode Optical Character Recognition (OCR) (Universitas Dian Nuswantoro). Retrieved from http://eprints.dinus.ac.id/18288/

Idhom, M., Alit, R., Endah, H., \& Fauzi, A. (2018). Implementation System Telegram Bot for Monitoring Linux Server. International Conference on Science and Technology (ICST 2018). Atlantis Press.

Pasurono, P., Handoko, S., \& Setyawan, I. (2013). Perancangan $\mathrm{kWh}$ meter digital menggunakan KWH meter konvensional. TRANSIENT, 2(1), 112-117.

Subito, M. (2012). Alat Pengukur Pemakaian Energi Listrik Menggunakan Sensor Optocoupler dan Mikrokontroler AT89S52. FORISTEK: Forum Teknik Elektro Dan Teknologi Informasi, 2(2). 
A Muafa, dkk / Teknika : Engineering and Sains Journal, Vol. 3, No.2, Desember 2019, 57-62

Halaman ini sengaja dikosongkan 